\title{
REVISITING EURO AREA ACCESSION TERMS: FISCAL RECTITUDE IS NOT SUFFICIENT!
}

\author{
DAIANU, Daniel
}

This paper argues that there are conditions for successful euro area (EA) accession, apart from fiscal rectitude. One is an ex ante critical mass of real convergence which should enhance lasting nominal convergence. Another condition is an overhaul of EA mechanisms and policies that should make it a properly functioning monetary union, which implies an adequate mix between risk-reduction and risk-sharing. It is argued that risk-sharing cannot be secured by private sector arrangements only. Entering the ERM2 is deemed to be no less demanding than euro area accession per se, especially for countries that use flexible exchange rate regimes. The paper examines also the influence of production (value) chains on the efficacy of autonomous monetary and exchange rate policies when it comes to controlling external imbalances; macro-prudential policies, too, are highlighted in this regard. Steady productivity gains are a must for surmounting the middle income trap and achieving sustainable real convergence.

Keywords: euro area accession, real convergence, euro area reforms, fiscal rectitude, risk-sharing, integration, fragmentation, global value chains (GVC)

JEL classification indices: F02, FM5, G01, H12, P52

Daniel Daianu, Professor of Economics at the National School of Political and Administrative Studies (SNSPA), Bucharest, and Member of the Board of the National Bank of Romania.

E-mail: daniel.daianu@bnro.ro 


\section{INTRODUCTION}

New Member States (NMS) are bound by the EU accession treaties to join the euro area (EA) eventually. But the financial crisis and the sovereign debt crisis have indicated that accession in the single currency area is not to be done irrespective of circumstances. The NMS that have larger economies are quite vague about their timetables for accession; the official view is that more real convergence is needed to this end. Bulgaria, which has a currency board, asked to enter into the Exchange Rate Mechanism2/ERM2 (which is the antechamber of the EA) in June 2018; the European Institutions considered this step to be premature. Croatia has targeted 2022-2023 as an accession moment. The Baltic countries, which have very small economies and had currency boards as their monetary policy regimes, joined the EA in succession: Estonia in 2011; Latvia in 2014; and Lithuania in 2015. Slovenia joined in 2007 and Slovakia did it in 2009 (while it joined the ERM2 in 2005), just before the eruption of the sovereign debt crisis in the EA.

Can "optimal" euro area accession terms be defined if straightforward political calculations are put aside? Do development gaps matter for euro area accession? What about the impact of production chains? Does the functioning of the EA matter? Lessons from the sovereign debt crisis in the EA seem to give an affirmative answer. But these issues are still controversial, not least in the NMSs. In Poland, for instance, Marek Belka has nuanced his earlier stance and argues in favour of faster accession ${ }^{1}$. Kolodko stresses that more important than When, is at What exchange rate it should be done (2017). Their position is counterbalanced by those who argue that more real convergence is needed for capitalizing on EA accession. Hungarian central bank economists argue that more real convergence, prior to accession, is needed (Nagy - Virág 2018). Darvas, instead, is quite sanguine about an early accession $(2017,2018)$. A role in this debate is presumably played by the middle income trap challenge. It may also be that, to the extent giving up autonomous monetary and exchange rate policy tools dents growth enhancing measures, EA accession delay is in the cards. In Romania, a line of reasoning favours early accession on political grounds primarily. Other views emphasize a critical mass of real convergence as a condition for accession (Daianu et al. 2017). The functioning of the EA as a policy issue is highlighted too (Daianu 2012).

Joining the EA is also to be judged in the context of a spreading "inward-looking syndrome” in Europe - against the backdrop of the Great Recession and other major adverse shocks (Daianu 2017). Destabilizing capital flows, which complicate the conduct of autonomous monetary policies (Rey), have also to be con-

His presentation at the Delphi Economic Forum, March 2018. Marek Belka was governor of the Polish Central Bank during 2010-2016. 
sidered. The Exchange Rate Mechanism (ERM) experience is a reminder of the power of destabilizing capital flows. And quite likely, this experience reinforced the rationale for the creation of the EMU $(\mathrm{EA})^{2}$, aside from its political dimension. But eliminating the currency risk does not eliminate the redenomination risk in a monetary union wherein heterogeneity and divergence are not kept in check.

The Treaty of Maastricht does not establish a clear timetable for euro area accession; the Treaty says, however, that each Member State has to reach lasting convergence to participate in the final stage of the European Monetary Union (EMU); this is a wording that alludes to ex ante real convergence. And entering the ERM2 (and staying there, successfully, for at least two years) is sine qua non for joining the EA.

This paper argues that there are conditions for successful euro area accession, apart from fiscal rectitude. One is the achievement of an ex ante critical mass of real convergence. Another condition is an overhaul of EA mechanisms and policies that should make it a properly functioning monetary union. The paper examines the influence of production (value) chains on the efficacy of autonomous monetary and exchange rate policies. The paper has four parts: Lessons from the functioning of the euro area; The governance of the EA; Production chains and macroeconomic adjustment; Reform attempts in the EA. A summing up part ends the paper.

\section{THE EURO AREA: DO DEVELOPMENT GAPS MATTER? ${ }^{3}$}

The EMU was set up even though it did not fit basic recommendations of the optimum currency area (OCA) theory ${ }^{4}$. A political rationale was quite likely at work in the decision made by the 11 founding EU member states, and the euro is considered to be the currency of the Union. Presumed benefits were taken into account, which can be described succinctly as follows:

- a credible ECB which would induce low interest rates for both short and longer term. From this perspective, the countries burdened with high and volatile inflation had the most to gain from EA accession;

- closer trade ties owing to the fall in transaction costs and the removal of the currency risk. Some analyses show that intra-euro area trade rose, on aver-

2 A fascinating account of the tremors of the ERM in the early 90s is provided by Keegan et al. (2017).

3 This section draws on Daianu et al. (2017).

4 The OCA theory was born out of the debate on the choice of either a fixed or a floating exchange rate. Mundell (1961) coined the OCA notion and clarified the circumstances in which a region/country could benefit from joining a currency union. 
age, by approximately 5-10\% (Baldwin 2006, Baldwin et al. 2008), but way lower than the initial forecast of $85 \%$ (Rose 2000);

- deeper financial integration due to lower risk premiums and lower capital cost;

- the end of speculative attacks on national currencies;

- political gains from closer economic links between EA member states.

The EA meant giving up the national currency as a policy tool as well as specific costs which were entailed by an imperfect EA functioning; the costs cca be summed up as: a diminution of the capacity to withstand shocks by relinquishing control over the own currency; capital flows that hid economic policy and structural weaknesses, and that fuelled a build-up of imbalances; the absence of a lender of last resort (de Grauwe 2011), as in a single currency area, a liquidity crisis can turn into a solvency crisis 5 .

\section{Inferences from the euro area travails}

The first 16 years of EMU functioning, as revealed by the dynamics of founding members' macroeconomic aggregates, show that ${ }^{6}$ :

- the income gaps at the time of accession was overly large in the EA, and that showed up in a divide in economic performances between the lower income and the higher income countries;

- the adoption of the single currency does not secure durable real convergence. The EA allowed some catching-up in terms of income/capita gaps at the cost of large external imbalances which called for costly correction policies, and from 2009 onwards part of real convergence was reversed;

- the single monetary policy was not adequate. The need for catching up in the poor countries acted as a perpetual asymmetric shock. Prices in these countries were systematically higher than in the rest of the euro area outpacing productivity gains (The Balassa-Samuelson effect). Real interest rates were lower than in the rest of the union, inviting over-indebtedness, and the real exchange rate steadily appreciated, jeopardising tradeables' competitiveness;

- the single currency caused investors to beleive the risks associated with cross-border capital flows in the EMU as having vanished. Massive capital flows went from the core to the periphery, much of it in non-tradeables sec-

5 Cohen-Setton - Vallee observe that the lender of last resort function needs to be improved in the euro area and that the ECB should be able to backstop financial markets in sovereign bonds (2018).

6 Praet (2014) stressed the "illusion of convergence before the crisis". 
tors, with devastating effects when they stopped and the periphery was left with an overly high labour cost to be competitive;

- the fiscal burden of periphery countries became so serious as to threaten payment default. Adjustment problems turned into fiscal emergencies;

- private sector debt overhang and the relationship with external deficits were underestimated. Private sector indebtedness built up swiftly, most notably in the countries that subsequently faced problems;

- the absence of a lender of last resort compounded the problem of liquidity squeeze and the sovereign default risk. Banks are sovereign debt holders, so that sovereign default risk entails the risk of bank failure that reinforces sovereign default risk.

The EA crisis and other similar episodes of turmoil (in Asia, for instance) have showed that large external imbalances have roots in private sector over indebtedness. Why is it so? Because capital flows from where it is saved to where it is "required" and where prospective yields seem to be higher. But capital flowed prevailingly into non-tradeables sectors. This is a big challenge posed by large development gaps. In the EA periphery countries the capital/head stock was much lower than in the North, thus inviting capital inflows. This was (and still is) also the case in Central and Eastern Europe (Figure 1 illustrates the boom and bust cycle during the past decade). Here is where the argument that big development gaps make no difference falters; that once a country has gained EA accession things work out the way they are supposed to, in keeping with the free movement of factors of production. In a world of perfect competition and factor price equalisation, this can occur. But competition is imperfect and imbalances are part of reality. And factor price equalisation can occur over the longer term, with large groups of winners and losers; this is where the strong backlash against borderless globalisation, around the world (and in Europe too), comes from.

A legitimate question is posed by Slovakia, which joined the EA in 2009, before the eruption of the sovereign debt crisis. It weathered relatively well the tremors in the EA (unlike Slovenia that went through a banking crisis and continued a catching up process which had started years before accession. This may have possibly been due, in part, to its industries having favourably become part of the "German value chains" (as an IMF study" suggests). Slovakia had a GDP/ head in PPS (purchasing power standards) around $60 \%$ of the EA average when it

7 "Starting in 1990s the rise of the German - Central European Supply Chain led to a rapid expansion in bilateral trade linkages between Germany and the Czech republic, Hungary, Poland, and the Slovak republic...Following the introduction of the euro, manufacturing activity stabilized in Northern euro area countries (Germany in particular) while it declined in Southern countries” (IMF 2018 January: 21, which quotes Vhiriälä - Wolff 2013). 
joined it. Does it invalidate the assumption that development gaps do not matter? Slovakia's case gives food for thought, but it hardly changes the broad picture. Section 3, which deals with the influence of production/value chains on macroeconomic corrections, provides additional insights into this matter.

\section{THE GOVERNANCE OF THE EURO AREA DOES MATTER}

There is a widely shared view that the design of the euro area was incomplete institutionally and policy-wise, while this area was far from an optimal currency area.
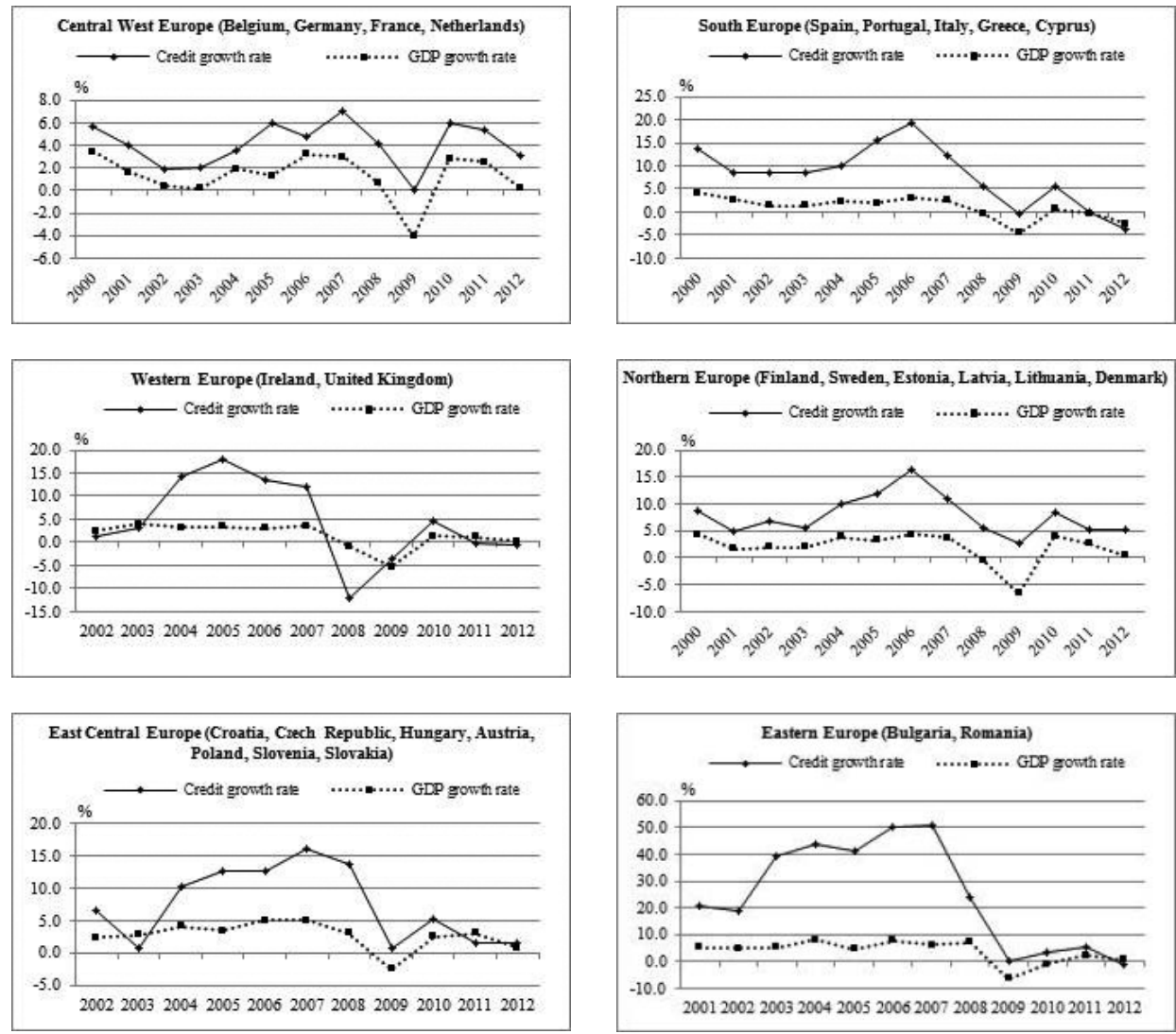

Figure 1. Banklending and GDPgrowth

Sources: Eurostat, European sector accounts (national central banks; other monetary financial institutions), own calculations ( Daianu 2015, in Nowotny et al. 2015: 201). 
For economies that are less competitive and register trade imbalances on recurrent basis key tools for correcting external imbalances are no longer available. At the surface, the euro area seems not to have a problem in this respect since creditor countries' surpluses more than compensate other member states' deficits. As a matter of fact, the euro area has a surplus vis-à-vis the rest of the world ${ }^{8}$.

Once the euro area crisis erupted, bond yields differed increasingly among member states, investors fleeing the paper of afflicted issuers and favouring German bonds in particular. These differentials came down again only following the start of the ECB's special operations - when the ECB decided to act as a de facto lender of last resort, although its statutes would not allow such a function. Internal devaluation, via drastic cuts of incomes (wages), did take place in various member states (Ireland, Greece, Spain, Portugal), and this helped the substantial reduction of external imbalances. But this correction instrument put social structures under enormous strain. And it is hard to assume that internal devaluation can be the main tool for correcting imbalances in the euro area on a recurrent basis. High public and private debts, high levels of non-performing loans in banks' balance-sheets ask for a wider range of correction mechanisms, including, arguably, debt restructuring. Bailing in schemes are part of the new means of dealing with high indebtedness and trying to protect tax payers' money, but they are not devoid of major pitfalls. The Italian episode of the last couple of years is telling in this respect. The attempt to sever the link between banks' balance-sheets and sovereign debt has not succeeded so far and it may be a futile endeavour if the objectives are not realistic and properly sequenced policies are not enacted (see Section 4). For, however damaged the trustworthiness of some member states may be, banks would likely continue to place sovereign debt among preferred assets. And this is because the only taxation power rests with governments. And it is questionable that the Banking Union (BU) can be the definitive solution to euro area's troubles.

What impedes a new design of the euro area when it comes to its governance and institutions? It is, first, a line of reasoning on the causes of the crisis which emphasises public indebtedness. But this is in contrast with what happened in Spain, Ireland and in other countries, where it is private borrowing that brought about the big troubles. Arguably, the suboptimal character of the single currency area combined with markets' myopia in bringing about failures of all sorts. It is very much true that public mood among citizens in creditor countries should not be underestimated, and that there are legal and constitutional reasons which do

8 The current account surplus of the euro area has been running at cca. 3\% of its cumulated GDP in recent years (EU statistics). 
play an important role in this equation. But the crucial explanation lies with the interpretation of the root causes of the euro area troubles.

Another explanation behind reform failures is not acknowledging the full extent of the EA precarious design. The BU is an attempt to reorder things in this respect. And there is undeniable progress achieved with the creation of the Single Supervisor Mechanism, the setting up of national resolution schemes. However, more needs to be done. The Single Resolution Fund, which is meant to help recapitalize banks, or help wind them down in an orderly fashion, is much too small as compared to banks' balance-sheets. And deposit insurance schemes remain national, while a collective scheme (EDIS) is missing. The ECB (and the European Stability Mechanism, too) will be around to intervene as a lender of last resort, and its operations would continue to be critical to forestall things getting out of control. But is it sufficient for the longer term?

The sketched description of the functioning of the euro area suggests that the interpretation of external imbalances needs a broader framework for analysis. The German external surplus (Figure 2) mirrors exceptional industrial and

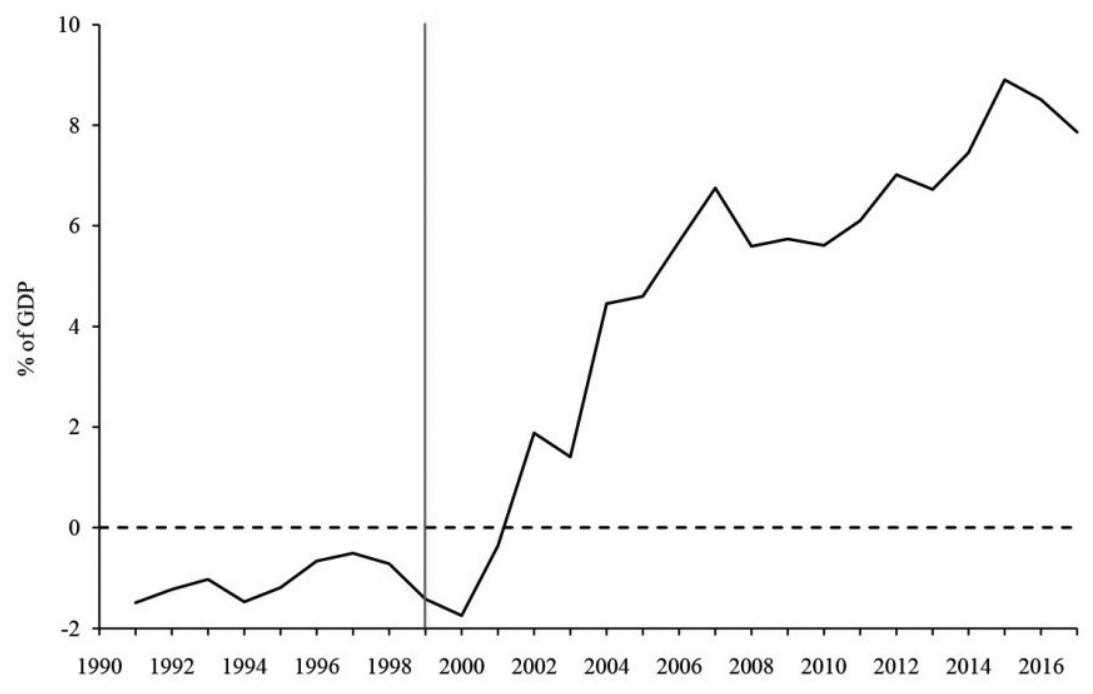

Figure 2. Germany's current account surplus according to EU data

Source: Eurostat.

Note: Vertical line denotes start of the euro.

9 It is telling that Isabel Schnabel, who is member of the German Council of Economic Experts, counteracts the stance of German banking associations who argue that EDIS would harm the interests of German savers (2018). 
trade capabilities. But the way the euro area has been functioning from its start made the euro operate as an undervalued currency for the large surplus countries (which bolsters exports and discourages imports, creates jobs, etc.) and as overvalued national currencies for the underperforming economies. Adjustments have taken place over the years. But these corrections have taken place primarily via a drastic compression of internal demand in those economies. Moreover, the new governance structure for monitoring imbalances (The European Semester, The Fiscal pact, The Excessive Deficit Procedure, eventually Competitiveness Councils, etc.), however useful it may be, is extremely complicated and cumbersome to implement. And the policy mix in the euro area has not matched expectations.

A union that does not have tools to combat asymmetric shocks and combat economic divergence is prone to go from one crisis to another.

\section{DO PRODUCTION CHAINS MATTER?}

Production chains can have a significant impact on macroeconomic corrections and this is a particularly interesting policy issue for the EA, as an integrated monetary (financial) space. Global production(value) chains (GVCs) embody economic interdependencies. Even if the Great Recession has entailed fragmentation and retrenchment (such as financial disintermediation, deleveraging, and world trade slowdown), cross-border production and financial chains stay strong and wideranging. In the European Union, these chains epitomize the Single Market Logic.

When substantial balance of payments imbalances emerge, which are caused by fundamental drivers, a traditional way to deal with them is to let the currency depreciate and combine it with public budget adjustment. The elasticity mechanism is at play in this working: how sensitive are exports to a higher local currency gain and how discouraged are imports when the local currency depreciates. Where production is competitive and made up, to a large extent, of tradables, elasticities can be quite significant; high elasticities can mitigate, or even prevent a J-curve effect (net exports go down before they go up); intended macroeconomic outcomes, via depreciation, occur without disruptive effects. An assumption here is that trading partners do not retaliate. For if they do, competitive devaluations would lead to mutual losses (beggar your neighbour policies).

Models that examine macro-economic adjustments that are triggered by exchange rate (real effective exchange rate) depreciations consider, in general, overall exports and imports. As a matter of fact, economic sectors can be highly diverse in terms of competitiveness, productivity levels. There are studies which illustrate the operation of production networks in Europe, in the world, and which highlight the feeble explanatory power of mono-sectorial models (Patel et al. 2017). 
Production chains get increasing salience when it comes to judging macroeconomic corrections. International networks can modify the impact of exchange rate depreciations on targeted changes in the production of tradeables. For instance, a study that uses OECD-WTO date and examines the experience of 46 countries, shows that, as against the period 1996-2003, total export elasticity in relation with the REER (real effective exchange rate) went down by almost $1 / 2$ during 2004-2012, from 1.3 to 0.6 (Ahmed et al. 2015).

A hypothesis can be submitted: the more exports contain intermediate imports, the less clear can be the impact of exchange rate depreciation on net exports. For net exports to be influenced more significantly by exchange rate depreciation it is necessary that the local value added contained by them be higher; only valued added measures the dynamics of national income and of productivity gains (other conditions being unchanged). The big struggle for economic catching up and for gaining more robustness (capacity to absorb shocks) depends, ultimately, not so much on being inserted in production chains, but on being in niches where higher value added is produced. Most emerging economies are passive agents in this respect since the players that create/shape global value chains are big international companies. EU integration is deep both in production (investment) and financial services (capital flows) - although fragmentation and retrenchment did take place after the eruption of the financial crisis. The Single Market logic plays a major role in this respect. In the EA links are reinforced by the existence of a common currency. The effects of the GVC are to be related to productivity dynamics (differentials). In economies where productivity gains lag behind, external imbalances tend to grow against the backdrop of a joint monetary policy (one size fits all monetary policy). The countries that make up "the periphery" of the EA have revealed an increasing divergence between their estimated equilibrium real effective exchange rates and the euro - after the introduction of the single currency. This means that the common currency became overvalued in their case (Dadush - Wyne 2012; Papanikos 2015; El-Shagi et al. 2016). Since correction via the exchange rate adjustment is no longer possible, it was replaced by domestic devaluation (control of wages and incomes) and sharp cuts in public expenditure - as it did happen after the eruption of the sovereign debt crisis.

The fracture between the North and the South reflects major differences in the functioning of institutions and markets (including what János Kornai called soft budget constraints decades ago), in production structures (tradeables vs. non-tradeables and the composition of the former ${ }^{10}$ ), inflation and wage differ-

10 Krugman had a very insightful observation when he anticipated that the introduction of the joint currency would lead to a Mezzogiornification of the southern fringe of the Union (1991: 80). 

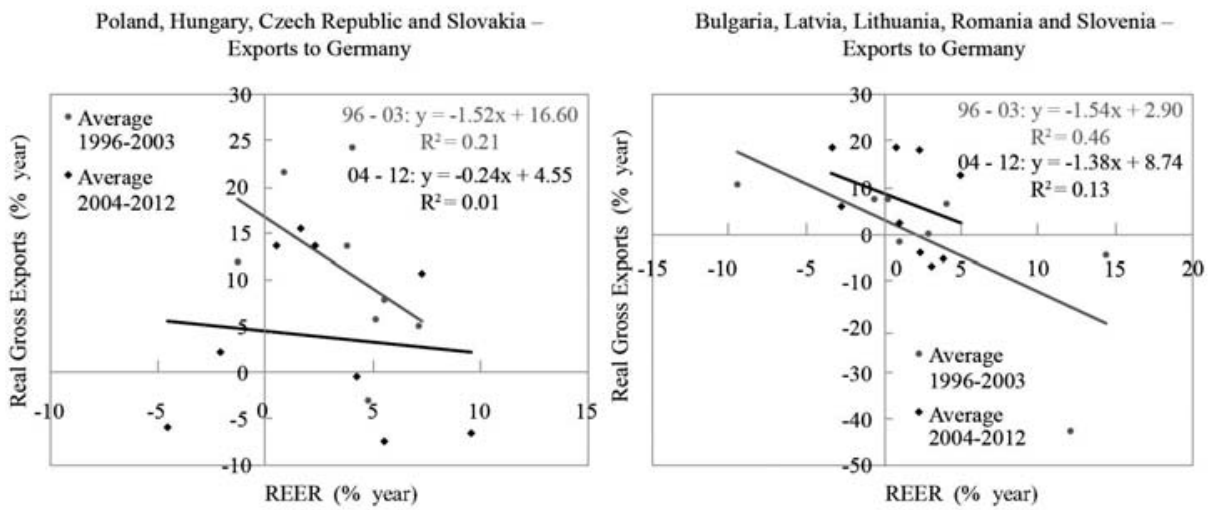

Figure 3. The growth of exports (\% annual) vs. the evolution of REER (\% annual) on German markets for two groups of countries

Source: Ahmed et al. (2015: 21).

entials ${ }^{11}$ - all of which boil down to considerable competitiveness gaps. And it is not easy at all to overcome chains/networks that, often, seem to have frozen. This is a key lesson for economies that wish to join the EA.

Studies that focus on European emerging economies indicate a fall in the responsiveness of net exports to exchange rate depreciation, especially where production networks are strong; this appears to be the case of Visegrad Group countries as against other emerging economies, such as Romania, Slovenia, Baltic countries (Ahmed et al. 2015). Figure 3 shows a flattening of the response function of net exports to REER for two groups of countries in the period 2004-2012 as against 1996-2003. This change of responsiveness of net exports to exchange rate depreciation seems to be linked with the economic development level and the inclusion in certain types of production chains. An IMF Study provides insights in this respect and suggests the formation of "German supply chains" in Central and Eastern Europe (Franks et al. 2018).

There is a dual inference for European emerging economies. First, it is essential for deeper integration into production chains to take place as advantageously as possible, namely in higher value activities. Second, structural compatibility is essential in a single currency area which lacks risk-sharing instruments and tools to deal with asymmetric shocks. It is worthy to notice that flexible exchange rate regimes appear to have enhanced economic recovery after 2009 (Behocine et al. 2016).

11 Even if GVCs are seen by some as levelling off inflation differentials (Auer et al. 2017). 
It seems that macroeconomic corrections are easier to undertake provided domestic value added is higher, cross-border chains do not diminish export and import elasticities excessively and, not least, productivity gains are steady. On what hinges a steady rise in the value added potential of an economy and its capacity to withstand shocks, to undertake macroeconomic adjustment? Some conjectures are submitted below:

- Systematic productivity gains, which should enhance moving higher up the value added chains;

- The educational level and skills of the population;

- The insertion in production chains that promote higher technologies;

- Policies that enhance the use of higher skilled labour;

- Wage policies which should try to stem human capital exodus. NMS face massive labour migration due to EU wage differentials. This puts pressure on local wages and can diminish competitiveness. This is a further argument in favour of considering policies that focus on getting access to higher value niches in the production chains;

- Local entrepreneurship - which can help innovation led economic growth tremendously. But this is a very scarce commodity;

- Macro-prudential tools to be used so that destabilizing capital flows be reduced. One needs to mention here the "financial channel", which can play havoc with an attempt to protect macroeconomic equilibria by not relaxing monetary conditions. ${ }^{12}$ Macro-prudential policies (capital controls) are needed in this context, as well as more attention must be given by reserve currency central banks (FED in particular) to the impact that their policies have on emerging economies.

A crucial question is whether GVCs make monetary policy and exchange rate policy irrelevant when macroeconomic adjustment is badly needed. Their efficacy can be dented when the responsiveness (elasticity) of net exports to exchange rate depreciation is diminished. But even if significant rigidities operate in this regard, the more diverse is production (be it made up of components to a large extent) and the larger an economy is, local costs can provide an important leeway for correction. The relevance of local costs depends on the value added created in an economy. And more resilient competitive advantages depend on the capacity to innovate and on steady productivity gains.

There is an ongoing debate and there are policy attempts in European emerging economies on how to get better niches in cross-border production chains, on how to upgrade them in value added terms; this debate and policy endeavour are also linked with the fear of not succumbing to the middle income trap.

12 For the distinction between the trade channel and the financial channel in judging the impact of the REER see Song Shin (2017). 


\section{REFORM OF THE EUROAREA: DISCIPLINE IS OF THE ESSENCE, BUT RISK-SHARING IS NO LESS IMPORTANT}

A significant economic recovery in the euro area (EA) has been underway in recent years. Nevertheless, major challenges still remain as the BU is incomplete and the EA is not yet robust enough when it comes to its tools and policy arrangements. This reality is acknowledged by high-ranking European officials and key official documents (ex: the Five Presidents' Report of 2015, the European Commission's Reflection Paper of 2017) as well.

\section{Two approaches on the reform of EA functioning}

EA reforms reveal essentially two approaches ${ }^{13}$. One approach emphasises financial discipline and rules. In a narrow sense, this approach boils down to balanced budget executions throughout the business cycle; in a broader sense, it implies rules that would not allow public and private imbalances to get out of control. But the financial crisis that erupted a decade ago has revealed vulnerabilities in the EA (see Sections 1 and 2 in this paper) that cannot be attributed to soft budget/financial constraints alone; resource allocation in a monetary union which features large development gaps among member states comes into play strongly. This is why the emergence of bubbles and their subsequent effects have to be considered. The other approach to reforms focuses on "risk sharing" within a union which is marked by heterogeneity, by member states' uneven capacity to absorb shocks. The EA is pretty diverse in this regard and the non-existence of key policy tools (e.g., an autonomous monetary policy and own lender of last resort) can be a big nuisance. Across the EA, there is a so-called "doom loop" between sovereign bonds and banks' balance sheets ${ }^{14}$. This loop is more of a problem when competitiveness gaps among member states are large and local banks show a proclivity for acquiring "local” government bonds (a bias which is enhanced by the zero-risk weights for sovereigns as well) ${ }^{15}$.

13 What lies behind these two approaches is dealt with in "The Euro and the Battle of Ideas", Brunnermeier et al. (2016). But the authors seem to downplay the role of the euro area inadequate design as an explanatory factor.

14 Sovereign bonds, when they are solid assets, strengthen banks' balance sheets and vice versa; banks count on state capacity to step in, when needed, either directly or indirectly (via central banks' operations).

15 Though one can argue that in exceptional circumstances, when market access is restricted, this preference can perform a significant shock-absorber function. 


\section{Risk reduction and risk sharing}

The non-standard operations of the ECB (including its lender of last resort (LoLR) operations) have rescued the EA. A big question is what will happen when the ECB normalises its policy, when interest rates revert, be it very gradually, to positive real levels. Although the correction of external imbalances (deficits) should not be underestimated in judging the reaction of financial markets, it is sensible to think that the current sovereign bond spreads of the "periphery" over the German Bunds (as a benchmark) do not illustrate member states' economic performances accurately.

EA creditor countries highlight the need to reduce NPL stocks (a legacy problem) as risk reduction measure, prior to implementing a risk-sharing scheme, such as a collective deposit insurance scheme in the banking sector. But, over time, the flow of non-performing loans hinges, essentially, on economic performance, and not on a particular level of NPLs, which can be brought down through various means ${ }^{16}$. In the absence of mechanisms and instruments that foster economic convergence in the EA, NPL stocks at national level would tend to diverge widely again.

One can imagine a diversification of banks' loan portfolio that would diminish the threats posed to their balance-sheets by activities in weaker economies. However, a complete decoupling of banks from weaker member states' economies is not realistic and not welcome, and contagion effects can still be significant. And if a decoupling by banking groups were attempted, that would cause further fragmentation in the EA - where finance is largely bank-based. Moreover, there are small- and medium-sized banks whose activity remains quasi-local/national.

A concern of creditor nations is that certain EA reforms would lead to systematic income transfers to some countries, to a "transfer union", which would call into question the political legitimacy of such arrangements. But a key distinction should be made in this respect: systematic transfers that would stick the "financially assisted" label to some economies should be distinguished from transfers that help cushion asymmetric shocks and narrow performance gaps. This distinction chimes with the logic of an insurance system.

It is worth mentioning, in this context, the bailing-in scheme (creditors' and shareholders' involvement in loss sharing, or haircuts). But bailing in can trigger contagion effects unless it is done with utmost care - and it is not clear that implacable rules are to be applied in this respect. The ECB was forced by a grim

16 As when non-performing loans in banks' balance sheets drop sharply when they are recognised as such (through write-offs), and not because the performance of the economy improves miraculously. 
reality to take on a de facto LoLR function from 2010 onwards; and one should not rule out bailouts under exceptional circumstances, when contagion effects may become very threatening.

If banking groups diversified their government bond portfolios while considerable competitiveness gaps persist among member states, and if sovereign bond ratings were no longer "risk-free", a strong preference for holding safer bonds would ensue. It can be inferred that, unless economic divergence among member states is mitigated, peripheral economies would become even more fragile once risk-weighted bonds come into being. The non-existence of proper risk-sharing schemes would only strengthen such perilous dynamics.

\section{A European "safe asset"}

The need to reduce the bank-sovereign doom loop as much as possible lies at the root of attempts to come up with a European safe asset. For years now, Eurobonds have been mentioned as risk-pooling assets that would make the EA more robust. However, mutualisation of risks is rejected by creditor nations, which do not accept the idea of a "transfer union". Hence the idea of a synthetic financial asset (sovereign bond-backed securities - SBBS) came up; this synthetic bond is derived from the pooling and slicing of sovereign bonds into three tranches: a senior one (deemed to be equivalent in strength to the German Bunds), a mezzanine (medium-risk) tranche, and a junior (seen as highly risky) tranche, with the latter bearing the brunt of losses in case of default (Sovereign bond-backed securities: a feasibility study, ESRB, Frankfurt am Main, January 2018).

But SBBS present a problematic feature: the supply of senior tranches depends fundamentally on the demand for junior tranches, and this demand is likely to fall dramatically during periods of market stress, when some member states' market access may be severely impaired. In those instances, demand will swiftly shift towards top-rated sovereign bonds, towards other safe assets. One can envisage a variation of the composition of SBBSs as a function of member states' market access, but this would make the whole scheme extremely cumbersome to implement. The fact is that, unless market access is secured for all member states, the supply of SBBSs turns too unreliable to make them a workable asset..

Apart from its functioning under conditions of market stress, the introduction of a synthetic asset (SBBS) should be judged in conjunction with a package of EA policy redesign measures. This package should cover inter alia:

- liquidity assistance available during times of market stress;

- schemes to cushion asymmetric shocks (a "fiscal capacity"); 
- sovereign debt restructuring should not be triggered automatically, for it may cause panic in the markets, more fragmentation in the EA;

- rules for adjusting imbalances should not be pro-cyclical;

- the macroeconomic imbalance procedure should operate symmetrically, for both external deficits and surpluses countries;

- a euro-area-wide macroeconomic policy that should reflect in the fiscal policy stance over the business cycle;

- investment programmes should foster economic convergence;

- no de-reregulation of finance (as it is attempted in the US currently).

As Buti et al. (2018) put it, "deepening EMU requires a coherent and well sequenced package”.

\section{What sort of financial integration in the EA?}

Financial integration in the EA, the establishment of a BU that includes a collective deposit insurance scheme, raises a fundamental issue: can the BU overcome market fragmentation and economic divergence in the absence of fiscal arrangements that would enable accommodation of asymmetric shocks and foster economic convergence. Some argue that a complete BU would dispense with the need of fiscal integration in the euro area ${ }^{17}$. But is it sufficient for a robust economic and monetary union that risk-sharing applies to finance (banks) only? And would private risk-sharing be sufficient to cope with systemic risks in financial markets? Relatedly, it is not clear that a collective deposit insurance scheme (EDIS) would involve private money only, under any circumstances; some fiscal risk-sharing may be needed in worst case scenarios ${ }^{18}$. What if economic divergence persists, or even deepens, since banks may discriminate among economies not least due to perceived risks that originate in bailing in schemes and other vulnerabilities? A disconnect between a BU, in which “'risk-sharing” operates, and real economies is hard to imagine; if economies would continue to diverge and risk-sharing would not apply to them too, that would undermine further the EA ${ }^{19}$.

Fiscal integration is the biggest hurdle to overcome in the EA since it calls for more than institutional cooperation; it involves institutional integration and

17 Sandbu says that a "banking union mimics fiscal risk-sharing” (2017).

18 In the US, The Federal Deposit Insurance Corporation (FDIC) is funded by private money, but it has behind it the US Government as the most trustworthy institution (the only one that has taxation power).

19 Smaghi argues that the most threatening doom-loop is between redenomination risk and sovereign risk; that this doom-loop can be contained by improving economic convergence and shock-absorbers (2018). Buti et al. also highlight the "redenomination risk” (2018). 
a significant EA budget as a form of risk-sharing ${ }^{20}$. But the latter leads to a huge political conundrum. And here lies a deeply going fragility in the design of the $\mathrm{EA}$, in the spirit of Dani Rodrik's trilemma, namely that there can be no integration (globalisation via a "single market") in cohabitation with an autonomous economic policy and democratic accountability at national level; something must be given up in this triumvirate. It is fair to argue that this trilemma simplifies things and that compromises can be found. And yet, it raises a formidable challenge to the EA functioning unless financial integration is accompanied by policy arrangements and mechanisms that combat growing divergence between member states. For excessive divergence would increasingly eat into the social fabric and fuel extremism, populism, Euroscepticism.

The progress of the $\mathrm{EA}$, of the $\mathrm{BU}$, demands a reconciliation between rules and discipline on one hand, and risk sharing (private and public) on the other hand (Benassy-Quere 2018). But an adequate calibration between rules and risksharing, between private and public risk-sharing, is an open question ${ }^{21}$.

Only private risk-sharing schemes would not make the EA more robust. Financial markets are too fickle and produce systemic risks recurrently; the Great Recession showed that public intervention was needed, ultimately, in order to avoid a catastrophe. Unless it will get adequate risk-sharing schemes, the EA will continue to be very rigid (like the gold standard regime) and prone to experience tensions and crises recurrently.

\section{SUMMING UP: CONDITIONS FOR SUCCESSFUL EURO AREA ACCESSION}

There are obvious benefits of joining EA, among which enhanced economic links between Member States' economies, lower transaction costs, no currency risk, a safe haven currency when financial markets are driven by destabilising flows,

20 "A banking union, however vital, is not enough. EMU also requires a fiscal union to take the edge off a country-specific macro-economic shocks. Established currency unions, such as those in large countries with multiple regional governments, include automatic risk-sharing mechanisms, the most efficient way to insure against business cycle risks” (Berger et al. 2018).

21 How to combine market discipline with risk-sharing is an open question and the fears of what may be an inadequate calibration between the two elements is obvious in Messori and Micossi 2018. Their view drew a rebuttal from Pisani-Ferry - Zettelmeyer (2018); Tabellini (2018) and Almunia et al. (2018) echo Messori and Micossi's concerns. The fact is that unless adequate risk-sharing is achieved, bad dynamics in the EA would further cripple it (see also Buti et al. 2018). 
a deeper insertion into European industrial networks. EA membership has also a strong geopolitical dimension in light of recent years' uncertainty, including Brexit and mighty centrifugal forces in the EU. Not least, the euro is part and parcel of the European (EU) project.

On the other hand, the argument that EA accession be as fast as possible is to be examined in a balanced way, for there are also lessons of the EA crisis not to be ignored: the euro area has deepened integration, but has failed to ensure sufficient convergence and has induced major imbalances (competitiveness gaps) between Northern Europe and Southern Europe; the need of structural and real convergence got more salience; the EA does not have yet in place instruments to withstand asymmetric shocks; policy space is tremendously relevant in the event of powerful adverse shocks and the EA allows, now, only domestic devaluation ${ }^{22}$ as a correction mechanism, which comes at a high social and political cost.

There is another issue that should not be overlooked - this is usually referred to as a 'battle of ideas', the difference between the Member States that rely on rules and those that prefer flexibility, discretionary intervention in the economy (Brunnermeier et al. 2016). The problem with this explanation, however, is that it underestimates the issue of mechanisms and policy arrangements within the EA.

When it comes to EA accession, two issues are critical: a/ whether there is need of a critical mass of convergence (robustness) ex-ante; and b/ whether the EA is properly functioning, which should encourage a Member State to join. Nominal criteria are not enough to gain EA membership. Rich empirical evidence shows that, unless structural features translate into lasting real convergence, a country's position in the EA is highly risky. These are not conjectures, but facts. The GDP/capita ratio relative to EA average increased in most of the EA periphery, but structural convergence was weak, ending up in major imbalances that called for broad-based corrective measures. Slovakia's experience provides food for thought as it may suggest that large development gaps should not make one less sanguine about fast accession. But the broad picture is not changed. Baltic countries are also examples that catching up can continue after EA accession. But they have very small economies and used currency boards as their monetary policy regimes prior to accession. In addition, Latvia and Lithuania went through very severe internal devaluations before joining the EA.

Across the EA, as it works today, the range of choices for managing imbalances is confined to the control fiscal and quasi-fiscal deficits in the public sector and to cut in wages and other income, as the case may be. One can argue that the

22 The concept came up during the economic crisis in Sweden in the '90s and Finland's accession to the EU in 1995. It gained prominence during the latest economic recession of 2008-2010 (Alho 2000:11). 
solution is to take macro-prudential steps in order to control credit to the private sector. But it is not at all clear whether these instruments will be sufficient, or what the impact of external funding on their efficacy will be. Another important policy issue is linked with inflation differentials. In countries with an income/ capita ratio considerably lower than the EA average, the inflation differential is likely to be quite significant. This means that, in time, unless productivity gains are appropriate external imbalances would widen.

Do global (European) production chains change the picture? They do to the extent an economy is well placed into these chains and systematic productivity gains take place. But is it a safe bet? It may be that some NMS are better positioned in this respect than the current "periphery" of the EA. And it is also true that most NMS are less indebted than the rest of the EU (EA). But these observations do not provide a peremptory argument for joining the EA without a proper degree of robustness. And the latter hinges on solid public finance (higher public revenues/fiscal space ${ }^{23}$ ) and the capacity to control external imbalances.

In spite of institutional and policies reforms, the EA still has important functioning flaws. It is true that currency risk is a thing of the past. Equally true is that the EA may help an economy to protect itself from destabilising capital movements. As Helene Rey put it, the trilemma of macroeconomic policy in an open economy boils down to a dilemma: a monetary policy seeking some degree of autonomy needs administrative control over capital movements, which is difficult when major central banks overlook the externalities of their own monetary policy decisions ${ }^{24}$. But Rey's argument is, arguably, not a decisive one in underplaying the EA's functioning.

For the countries that use managed floating, entering the ERM2 is hardly less demanding than joining the EA; in order to operate well within the ERM2 an economy needs to have solid public finance and keep external imbalances under control. This policy outcome depends on robustness, an adequate policy mix and tested macro-prudential tools when it comes to private credit binges. Croatia, Hungary, Poland, Romania, The Czech Republic enter in this category. Bulgaria may have a shorter path since it has a currency board as its monetary policy arrangement.

There is thus need to identify the best way between reaching a critical mass of real and structural convergence (robustness) ex ante, counting also on reform measures in the EA to make it function better. EA accession can be hastened for

23 Fiscal space is like having money in the bank (Haksar et al. 2018).

24 Obstfeld et al. (2018) are nuanced in judging the usefulness of a floating exchange rate regime in emerging markets in the face of substantial capital flows. 
geopolitical reasons. This choice, however, must be based on solid economic data and balanced judgements.

Non-euroarea NMSs must get involved in rethinking how the Single Market works so as to benefit as many citizens as possible. Without inclusive economic processes that should be characterised, inter alia, by fairness and transparency, social cohesion will be increasingly damaged. The European Union should not be idealized; the reality is fairly nuanced and the "single market" exudes rapports de force, unfair competition not infrequently. The Union itself is at a crossroads and, unfortunately, the solidarity principle among the Member States often appears to be put on the shelf. A big issue is made up of growing mistrust gaps between governments and citizens, between governments and European institutions, between the latter, generally the elites, and citizens.

Brexit, which stands for a far-reaching syndrome across the European Union, has fuelled anxiety and great uncertainty. European economies are faced with great challenges if we think about the drawbacks of over-financialisation, the fall-out from the financial and economic crisis, debt overhang, eroded social cohesion, immigration, bad practicies in the business world, an "inward-looking syndrome" (see the Appendix). 


\section{APPENDIX \\ An "inward looking syndrome" (simple analytics of a trade-off)}

Dilemmas which contort a society when facing major threats can be captured by economic analysis. Thus, one can relate protection (security) to openness (economic freedom) seen as public goods. This can be illustrated as a social utility function which includes protection (S) and economic freedom $(\mathbf{O})$ as public goods. A function $\mathrm{F}=\mathrm{F}(\mathrm{S}, \mathrm{O})$ would indicate levels of citizens' comfort in terms of these public goods; it could look like $\mathbf{F}=(\mathbf{( 1 - a )} \mathbf{x S}+\mathbf{a} \mathbf{x O})$, where (a) would be a variable in conformity with people's attitude toward the two public goods; this variable could not be higher than 1 and not lower than 0 . The substitution between protection (security) measures and economic openness has limits because these two public goods are not completely independent of each other; from a certain level, protection measures (including restrictions) may distort democracy exceedingly. Likewise, a total openness of the economy/society, with no rules and protection measures, may cause social anomia.

Various combinations of (S) and (O) may be imagined so as to ensure a degree of citizens' acceptance that would minimize discontent/discomfort in given conditions. An optimal combination is where the price line $(\mathrm{S}, \mathrm{O})$ is tangent to the preference (social choice) curve (I). The (a) point refers to an initial level of economic freedom - as flows of capital, workforce, investment, and the range and scope of regulations. At point (a) things are relatively good, calm, and this is revealed by the price line between $(\mathrm{S})$ and $(\mathrm{O})$; a steeper slope, $\mathrm{P}_{\mathrm{a}}$, shows that (S) is regarded as being sufficient (people feel safe) and economic openness as a public good is in high demand

When times worsen a more inward looking society emerges; such a turnaround is revealed by the change in preferences in favor of (S). When the need for protection measures grows, the change is reflected by a less steep slope of the relative price, $\left(\mathrm{P}_{\mathrm{b}}\right)$, between $(\mathrm{S})$ and economic openness $(\mathrm{O})$; this may involve protectionism and other restrictive measures and their combination is indicated by point (b) on the indifference (utility) curve.

The graph below simplifies reality not least because it refers to people in general, but, nonetheless, is not irrelevant. Who decides and how decisions are made regarding the two public goods brings politics into the limelight, as citizens may have different options, may share different political views or values; a community may be made up of different ethnical groups and religions, a large part of the population could be made up of immigrants, etc. In a democracy, one is tempted to say that the social collective option (social) is given by the majority vote. But things are much more complicated if society is profoundly divided and various 


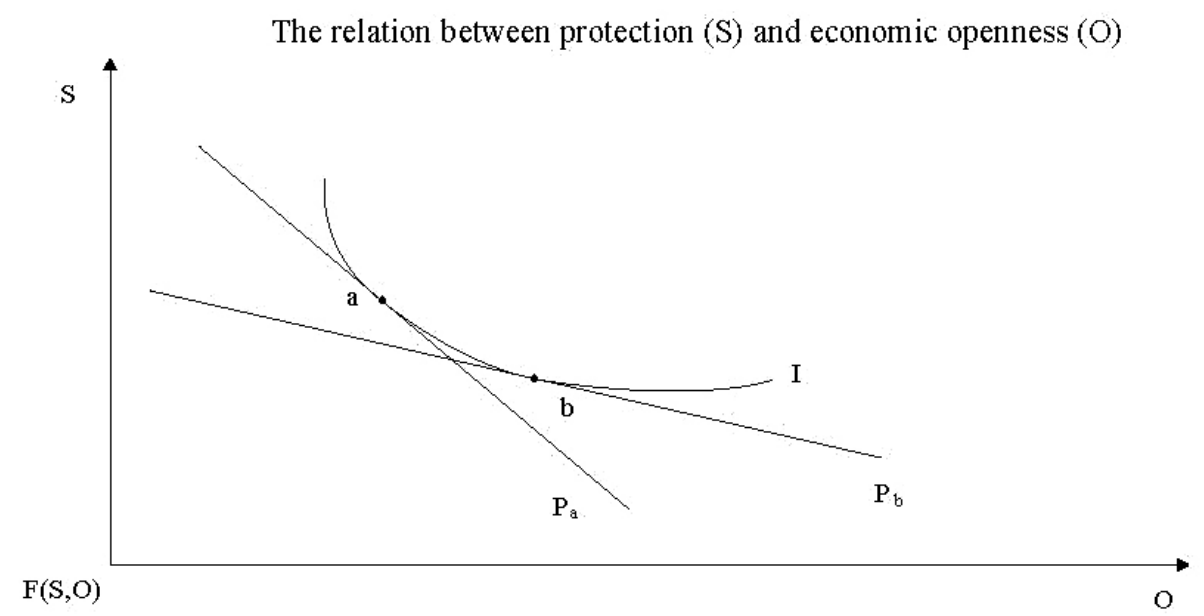

values are guiding people' choices. Moreover, economic interdependencies between states may be very strong.

It is also a fact that the way people value protection vs. openness may vary over time. What is abnormal, unpalatable today, may be termed differently at another moment in time; it may be that people adjust to different circumstances, their habits change.

Protection measures can trigger similar responses from partners - and trade wars will likely lead to damages for all parties involved. Therefore, any measures at a national level should be pondered given potential answers from partners. The analysis should be adapted for the case of economic and military alliances. For example, within the EU there is a pressing need for common efforts in the area of intelligence, border protection, and military defense - as all these are European public goods. There are additional aspects that can help to see through future trends: the global economy gets multipolar; the EU is fragmented by centrifugal forces and weakened by Brexit; the post WWII institutional economic arrangements (“'Bretton Woods's arrangements") are under siege due to alternative accords and institutions; unrestrained globalization has brought benefits, but it has also damaged social cohesion by neglecting distributional effects; "Realpolitik", as a way to articulate foreign policies, goes up at the expense of placing moral values and the interests of what is called the "international community" at center stage. 


\section{REFERENCES}

Ahmed, A. - Appendino, M. A. - Ruta, M. (2015): Depreciations without Exports? Global Value Chains and the Exchange Rate Elasticity of Exports. World Bank Policy Research Working Paper, No. 7390.

Alho, K. E. O. (2000): Social Implication of EMU. Finland. The Research Institute of the Finnish Economy (ETLA), Helsinki. Available at http://edz.bib.uni-mannheim.de/daten/edz-ma/esl/00/ ef0036en.pdf

Almunia, J. - Anchuelo, A. - Borrell, J. - Vegara, D. (2018): Quit Kicking the Can Down the Road. A Spanish View of EMU Reforms. Bruegel.

Auer, R. - Levtchenko, A. - Sure, P. (2017): International Inflation Spillovers through Input Linkages. CEPR Discussion Paper, No. 11906.

Baldwin, R. (2006): The Euro's Trade Effects. ECB Working Paper, No. 594.

Baldwin, R. - DiNino, V. - Fontagné, L. - De Santis, R. - Taglioni, D. (2008): Study of the Impact of the Euro on Trade and Foreign Direct Investment. European Economy, Economic Papers, No. 321.

Belhocine, N. - Crivelli, E. - Geng, N. - Scutaru, T. - Wiegand, J. - Zhan, Z. (2016): Reassessing Monetary and Exchange Rate Regimes in Emerging Europe. IMF Presentation, Bucharest, May.

Belka, M. (2018): Speech at the Delphi Economic Forum, March.

Benassy-Quere, A. - Brunnermeier, M. - Enderlein, H. - Fahri, E. - Fratzscher, M. - Fuest, C. Gourinchas, P. O. - Martin, Ph. - Pisani Ferry, J. - Rey, H. - Schnabel, I. - Veron, N. - Weder di Mauro, B. - Zettelmeyer, J. (2018): Reconciling Risk Sharing with Market Discipline: A Constructive Approach to Euro Area Reform. CEPR Policy Insight, No. 91, January.

Berger, H. - Dell'Ariccia, G. - Obstfeld, M. (2018): The Euroa Area Needs a Fiscal Union. IMF Blog, 21 February.

Bini Smaghi, L. (2018): Reconciling Risk-Sharing with Market Discipline. Policy Brief, LUISS, SEPE, 30 January.

Brunnermeier, M. L. - James, H. - Landau, J. P. (2016): The Euro and the Battle of Ideas. Princeton University Press.

Brunnermeier, M. K. - Garicano, L. - Lane, Ph. R. - Pagano, M. - Reis, R. - Santos, T. - Thesmar, D. - Van Nieuwerburgh, S. - Vayanos, D. (2011): European Safe Bonds (ESBies). The Euronomics Group.

Buti, M. - Giudice, G. - Leandro, J. (2018): Deepening EMU Requires a Coherent and Well Sequenced Package. VoxEU, 25 April.

Cohen-Setton, J. - Vallee, S. (2018): Euro Area Reform cannot Ignore the Monetary Realm. VoxEU, 20 June.

Dadush, U. - Wyne, Z. (2012): Is the Euro Rescue Succeeding? VoxEU, 20 April.

Daianu, D. (2012): Euro Zone Crisis and EU Governance: Tackling a Flawed Design and Inadequate Policy Arrangements. Acta Oeconomica, 62(3): 295-319.

Daianu, D. (2015): A Central Bank's Dilemmas in Highly Uncertain Times: A Romanian View. In: Nowotny, E. - Ritzberger-Grunwald, D. - Schuberth, H. (eds): The Challenge of Economic Rebalancing in Europe, Perspectives for CESEE Countries. London: Edward Elgar Publishing, pp. 194-221.

Daianu, D. (2017): The New Protectionism. World Commerce Review, Spring.

Daianu, D. (2018): Emerging Europe and The Great Recession. Newcastle upon Tyne, UK: Cambridge Scholars Publishing. 
Daianu, D. - Kállai, E. - Mihailovici, G. - Socol, A. (2016): Romania's Euro Area Accession: The Big Question is under What Terms to be Done. European Institute of Romania. Available at http://www.ier.ro/sites/default/files/pdf/SPOS_2016_Romania_si_aderarea_la_zona_euro.pdf. A highly downsized version was published in 2017 by the Romanian Journal of European Affairs, 17(2): 5-29 and is also to be found in Daianu (2018).

Darvas, Zs. (2018): Should Central European Members Join the Euro Zone? Bruegel, 11 September.

Darvas, Zs. - Scott, T. (2017): Euro Area Enlargement: A New Opening? Brussels, Bruegel, 2 November.

De Grauwe, P. (2011): The Governance of a Fragile Eurozone. CEPS Working Documents, Economic Policy, May.

De Grauwe, P. (2012): In Search of Symmetry in the Eurozone. CEPS Commentary, 2 May.

Draghi, M. (2012): Presentation at Global Investment Conference, London, 26 July. Available at https://www.youtube.com/watch?v=7jPE8hqrhOw

Eichengreen, B. (1991): Is Europe an Optimum Currency Area? NBER Working Papers, No. 3579. Available at http://ideas.repec.org/p/nbr/nberwo/3579.html

El-Shagi, M. - Lindner, A. - von Schweinitz, G. (2016): Real Effective Exchange Rate Misalignment in the Euro Area. Review of International Economics, 24(1): 37-66.

European Commission (2015): Completing Europe's Economic and Monetary Union. Report by Jean-Claude Juncker, in close cooperation with Donald Tusk, Jeroen Dijsselbloem, Mario Draghi, and Martin Schulz (the so-called Five Presidents'Report). Available at http://ec.europa. eu/priorities/sites/beta-political/files/5-presidents-report_ro.pdf

European Commission (2017): Reflection Paper on the Deepening of the Economic and Monetary Union. COM, 31 May.

Franks, J. - Barkbu, B. - Blavy, R. - Oman, W. - Schoellerman, H. (2018): Economic Convergence in the Euro Area: Coming Together or Drifting Apart. IMF Working Paper, No.10, January.

Glick, R. - Rose, A. K. (2015): Currency Unions and Trade: A Post-EMU Mea Culpa. NBER Working Paper, No. 21535.

IMF (2017): Euro Area Policies. Selected Issues. IMF Country Report, No.17.

Haksar, V. - Moreno-Badia, M. - Patilla, K. - Syed, M. (2018): Economic Preparedness: The Need for Fiscal Space. IMF Blog, 27 June.

Keegan, W. - Marsh, D. - Roberts, R. (2017): Six Days in September. Black Wednesday, Brexit and the Making of Europe. London: OMFIF.

Kolodko, G. (2017): Economics and Politics of the Currency Convergence: the Case of Poland, Communist and Post-Communist Studies, 50(3): 183-194.

Kolodko, G. - Postula, M. (2018): Determinants and Implications of the Eurozone Enlargement. Acta Oeconomica, 68(4): 477-498.

Kornai, J. (1980): The Shortage Economy. Amsterdam: North-Holland.

Krugman, P. (1991): Geography and Trade. Cambridge: MIT Press.

Messori, M. - Micossi, S. (2018): Counterproductive Proposals on Euroarea Reform. CEPS Policy Insight, No.2018, Brussels, February.

Mundell, R. (1961): A Theory of Optimal Currency Areas. The American Economic Review, 51(4): 657-665.

Nagy, M. - Virág, B. (2018): Accession to the Euro Area - From the Standpoint of the Magyar Nemzeti Bank. Budapest: MNB.

Nowotny, E. - Ritzberger-Grunwald, D. - Schuberth, H. (eds): The Challenge of Economic Rebalancing in Europe, Perspectives for CESEE Countries. London: Edward Elgar Publishing. 
Obstfeld, M. - Ostry, J. - Quereshi, M. (2018): Global Financial Cycles and the Exchange Rate Regime: A Perspective from Emerging Markets. American Economic Review, Papers and Proceedings, No. 108, May, pp. 499-504.

Otero-Iglesias, M. - Royo, S. - Steinberg, F. (2016): The Spanish Financial Crisis: Lessons for European Banking Union. Madrid: Real Instituto Elcano.

Pisani-Ferry, J. - Zettelmeyer, J. (2018): Messori and Micossi’s Reading Is a Misrepresentation. CEPS Commentary, 19 February.

Praet, P. (2014): The Financial Cycle and Real Convergence in the Euro. Presentation at the Annual Hyman P. Minsky Conference on the State of the US and World Economies, Washington, D. C., April 10.

Patel, P. - Wang, Z. - Wi, S. (2017): Global Value Chains and Effective Exchange Rates at the Country-Sector Level. BIS Working Papers, No. 637.

Rey, H. (2013): Dilemma not Trilemma: The Global Financial Cycle and Monetary Policy Independence. Paper presented at the Jackson Hole Symposium, August. Available at http://www. kansascityfed.org/publications/research/escp/escp-2013.cfm. Re-edited in 2015 as NBER Working Paper, No. 21162, May 2015.

Rose, A. (2000): One Money, One Market: Estimating the Effect of Common Currencies on Trade. Economic Policy, 15(30): 7-46.

Sandbu, M. (2017): Banking Union would Transform Europe’s Politics. Financial Times, 25 July. Schnabel, I. (2018): How to Break the Bank-Sovereign Doom Loop. Financial Times, 29 August.

Song Sin, H. (2017): Monetary Policy Challenges Posed by Global Liquidity. Speech at High Level Roundtable on Central Banking in Asia, 50th ADB Annual Meeting, Yokohama, 6 May.

Tabellini, G. (2018): Risk Sharing and Market Discipline: Finding the Right Mix. VoxEU, 16 July. Vihriälä, E. - Wolff, G. B. (2013): Manufacturing as a Source of Growth for Southern Europe, Opportunities and Obstacles. In: Veugelers, R. (ed.): Manufacturing Europe's Future. Bruegel Blueprint Series, No. XXI, pp. 48-72. 